\title{
PENENTUAN SIKLUS JADWAL PEMASUKAN DAY OLD CHICK (DOC) PADA PLASMA MITRA UNTUK MEMINIMUMKAN JARAK TEMPUH PETUGAS PENYULUH LAPANGAN (PPL) PT. X UNIT KEDIRI
}

\author{
Elly Ismiyah \\ Program Studi Teknik Industri \\ Universitas Muhammadiyah Gresik \\ Email : ismi elly@yahoo.com
}

\begin{abstract}
Abstrak
$\mathrm{P}$ ersaingan dalam dunia industri saat ini semakin meningkat, tidak terkecuali dalam perusahaan yang bergerak di bidang peternakan khususnya penggemukan ayam pedaging. PT. X unit Kediri merupakan salah satu perusahaan yang bergerak dalam bidang tersebut, perusahaan dituntut untuk dapat beroperasi secara excellence sehingga mampu menciptakan harga yang kompetitif dengan kualitas dan pengiriman sesuai yang diharapkan. Salah satu cara yang dapat dilakukan untuk mencapai excellence adalah dengan menerapkan konsep lean dalam kegiatan operasionalnya yaitu meminimasi waste yang muncul, termasuk kegiatan transportasi berlebihan yang dilakukan oleh Petugas Penyuluh Lapangan (PPL) dalam melakukan kunjungan ke peternak mitra (plasma) untuk mengawasi manajemen pengelolaan plasma. Manajemen peiharaan yang komplek mulai dari persiapan pemasukan Day Old Chick(DOC) hingga pemanenan ditambah dengan pengetahuan peternak yang beragam menjadi tantangan bagi PPL untuk dapat menghasilkan ayam pedaging dengan performansi yang tinggi. Namun, seringkali waktu yang dimiliki PPL banyak tersita untuk kegiatan transportasi dari satu plasma ke plasma yang rutenya bisa jadi tidak efisien karena adanya aturan bahwa ayam yang berumur lebih muda atau yang pemasukan DOC nya paling akhir adalah yang harus dikunjungi terlebih dahulu. Kegiatan transportasi yang berlebihan tersebut dapat dikatakan sebagai waste dan dapat diminimasi dengan melakukan perencanaan yang baik pada jadwal pemasukan DOC. Pada penelitian ini siklus jadwal DOC akan dibuat berdasarkan rute yang harus dikunjungi setiap PPL yang telah ditentukan dengan metode saving matrix dan metode nearest neighbor untuk urutan dalam setiap rutenya. Pemasukan DOC dilakukan dengan membalik urutan dalam rute tersebut, sehingga plasma dengan ayam yang lebih dulu masuk kandang (umur lebih tua) akan dikunjungi pada urutan terakhir.
\end{abstract}

\section{Kata Kunci : Transportasi PPL, Jadwal pemasukan DOC, Saving matrix, Nearest Neighbour}

\section{PENDAHULUAN}

\section{Latar Belakang}

Dengan semakin meningkatnya persaingan industri, tidak terkecuali industri peternakan maka perusahaanterusdituntutuntukbisaberoperasi secara excellence, salah satunya dengan beroperasi secara efisien dalam kegiatan operasionalnya sehingga dapat menciptakan harga yang kompetitif, dengan kualitas dan pengiriman sesuai yang diharapkan. Salah satu cara yang dapat dilakukan untuk mencapai excellence adalah dengan menerapkan konsep lean dalam kegiatan operasionalnya, yaitu dengan meminimasi waste yang muncul. Transportasi merupakan salah satu kegiatan yang tidak dapat dihindari dan mutlak diperlukan, serta merupakan komponen biaya operasional yang cukup tinggi bagi sebuah perusahaan. Tetapi kegiatan transportasi akan menjadi salah satu bentuk waste jika kegiatan tersebut berlebihan sepanjang proses value stream (Gasperz, 2007).

PT. X merupakan perusahaan yang bergerak di bidang peternakan khususnya penggemukan ayam pedaging melalui kemitraan yang selanjutnya disebut dengan "plasma". Salah satu unit yang dimiliki berlokasi di kota Kediri. Sebagai perusahaan yang bisnis intinya dijalankan melalui kemitraan, perusahaan dihadapkan pada beragamnya pengetahuan yang dimiliki oleh peternak mitranya dalam melakukan manajemen pengelolaan plasma. Untuk itu Petugas Penyuluh Lapangan (PPL) memiliki peran yang sangat penting dalam mengarahkan dan memantau manajemen yang dilakukan oleh masing-masing plasma. Manajemen yang dilakukan oleh peternak plasma yaitu dimulai dari persiapan kandang, pemasukan DOC, proses selama penggemukan ayam yang terdri dari pemberian pakan dan air minum, pengaturan temperatur brooder, pengaturan ventilasi, pencatatan atau recording, penanganan kesehatan, sampai pada proses pemanenan hasil. Keberhasilan dalam melakukan manajemen mengenai hal di atas tidak bisa terlepas 
dari peran PPL sehingga waktu yang dimiliki PPL menjadi sangat berharga. Semakin baik hubungan kemitraan semakin efektif saluran distribusi yang digunakan. Hal yang perlu diperhatikan dalam kemitraan adalah hubungan yang adil karena kemitraan dalam saluran distribusi yang didasarkan atas saling percaya (trust) dan keadilan (fairness) merupakan nilai kekayaan (asset) yang strategis. Kontrol, kunjungan ke kandang secara rutin yang dilakukan oleh inti terhadap peternak mitra sangat membantu keberhasilan usaha (Sofyan, 2006)

Plasma yang harus ditangani oleh setiap PPL dapat dikatakan cukup banyak yaitu rata-rata mencapai 30 plasma dengan jarak antar plasma yang beragam, sementara para PPL memiliki keterbatasan dalam hal jam kerja. Selain batasan jam kerja, dalam kasus kunjungan PPL ke plasma harus juga didasarkan pada umur ayam. Plasma dengan umur ayam lebih kecil (pemasukan DOC paling akhir) harus dikunjungi terlebih dahulu. Selama ini perusahaan maupun PPL tidak memiliki aturan atau siklus jadwal plasma mana yang akan menerima DOC dari pusat, pemilihan plasma bersifat acak dan hanya didasarkan pada aspek kesiapan plasma dalam menerima DOC sehingga terkadang rute yang dilalui PPL dalam melakukan kunjungan menjadi tidak efisien karena harus mengikuti aturan tersebut. dan waktu dari PPL banyak tersita untuk perjalanan.

Perumusan Masalah

Berdasarkan latar belakang di atas, peneliti berupaya untuk menemukan jawaban atas pertanyaan "Bagaimana siklus jadwal pemasukan DOC pada plasma mitra untuk mengoptimalkan jarak tempuh PPL PT. X Unit Kediri?"

Tujuan Penelitian

Tujuan yang hendak dicapai adalah :

1. Menentukan rute yang harus dikunjungi PPL setiap harinya dengan metode Saving Matrix

2. Menentukan siklus jadwal pemasukan DOC pada masing-masing plasma berdasarkan rute optimal yang harus dikunjungi PPL.

\section{Manfaat Penelitian}

Manfaat yang dapat diberikan antara lain:

1. Jarak tempuh PPL menjadi lebih optimal (minimal) sehingga waktu yang dimiliki dapat digunakan untuk lebih fokus terhadap pekerjaan.
2. Perusahaan memiliki acuan siklus jadwal pemasukanDOCpadaplasmamitranyayangdapat menghemat biaya transportasi yang dikeluarkan.

\section{Ruang Lingkup Penelitian}

Penelitian dilakukan terhadap semua plasma yang menjadi mitra PT. X dimana jarak dari kantor unit dengan plasma maupun jarak antar plasma diidentifikasi dengan bantuan google map dengan mengambil satuan jarak kilometer. Sedangkan dalam penentuan rute kunjungan digunakan asumsi bahwa semua ayam dalam kondisi normal atau sehat.

\section{TINJAUAN PUSTAKA}

\section{Manajemen Pemeliharaan Ayam Pedaging}

Untuk menghasilkan ayam pedaging yang sehat sehingga dapat dipanen sesuai dengan berat yang diminta oleh customer atau pembeli maka diperlukan manajemen pengelolaan dan pemeliharaan yang sesuai dengan standar yang sudah ditetapkan. Manajemen pemeliharaan tersebut antara lain (Sholikin, 2011) :

1. Persiapan kandang yang terdiri dari pencucian dan sterilisasi kandang dan peralatan yang ada di dalamnya dan pemasangan pemanas dan lingkaran (brooding)

2. Pemasukan Day Old Chick (DOC), yang harus dilakukan pada saat pemasukan DOC adalah pengecekankualitas maupun kuantitas dariDOC.

3. Pengaturan temperatur brooder. Temperatur yang tepat adalah $34-35^{\circ} \mathrm{C}$ pada minggu pertama, $29-30^{\circ} \mathrm{C}$ pada hari ke 9 dan melepas pemanas pada umur 11 hari.

4. Pemberian pakan dan air minum. Pakan yang diberikan harus selalu bersih dan segar, sementara pemberian air minum harus disesuaikan dengan temperature dan diberikan secara at libitum

5. Pengaturan ventilasi, dengan cara menutup dan membuka tirai kandang,

6. Pencatatan atau recording laporan harian, yang terdiri dari laporan jumlah kematian ayam, pemberian pakan, obat, dan vaksin,serta penimbangan berat badan mingguan.

7. Proses Pemanenan. 
Kegiatan Transportasi dan Transportasi sebagai Salah Satu Waste

Transportasi merupakan bagian penting dalam kehidupan masyarakat, karena memiliki manfaat ekonomi, sosial, politik, maupun manfaat kewilayahan. Dengan kegiatan transportasi suatu produk dapat dihantarkan sampai ke tangan pembeli, masyarakat dapat menuju tempat yang mereka butuhkan (sekolah, bekerja, rekreasi, dan lain-lain), dan persatuan nasional juga dapat tercapai karena suatu wilayah tidak lagi terisolasi satu sama lain. Dengan adanya peningkatan kebutuhan penduduk maka kegiatan transportasi juga ikut meningkat, termasuk untuk kebutuhan bisnis dan industri. Menurut Chopra,Meindl, dalam Erlina (2009), Metode transportasi merupakan suatu model yang digunakan untuk mengatur distribusi dari sumbersumber yang menyediakan produk yang utama ke tempat-tempat yang membutuhkan secara optimal. Alokasi produk ini harus diatur sedemikian rupa, karena terdapat perbedaan biaya-biaya alokasi dari satu sumber ke tempat tujuan-tujun yang bebeda.

Gasperz (2007) dalam bukunya yang berjudul "Lean Six Sigma" telah menciptakan akronim : E-DOWNTIME untuk memudahkan praktisi bisnis dan industri mengidentifikasi 9 jenis pemborosan yang selalu ada dalam bisnis dan industri, salah satunya adalah transportasi yang berlebihan sepanjang proses value stream. Secara lengkap pemborosan itu adalah :

$\mathrm{E}=$ Environmental, Health and Safety (EHS), jenis pemborosan yang terjadi karena kelalaian dalam memperhatikan hal-hal yang berkaitan dengan prinsip-prinsip EHS.

$\mathrm{D}=$ Defects, jenis pemborosan yang terjadi karena kecacatan atau kegagalan produk (barang dan/atau jasa)

$\mathrm{O}=$ Overproduction, jenis pemborosan yang terjadi karena produksi melebihi kuantitas yang dipesan oleh pelanggan

$\mathrm{W}=$ Waiting, jenis pemborosan yang terjadi karena menunggu

$\mathrm{N}=$ Not utilizing employees knowledge, skills and abilities, jenis pemborosan sumber daya manusia (SDM) yang terjadi karena tidak menggunakan pengetahuan, keterampilan dan kemampuan karyawan secara optimum

$\mathrm{T}=$ Transportation, jenis pemborosan yang terjadi karena transportasi yang berlebihan sepanjang proses value stream.

$\mathrm{I}=$ Inventories, jenis pemborosan yang terjadi karena inventories yang berlebihan.

$\mathrm{M}=$ Motion, jenis pemborosan yang terjadi karena pergerakan yang lebih banyak daripada yang seharusnya sepanjang proses value stream.

$\mathrm{E}=$ Excess processing, jenis pemborosan yang terjadi karena langkah-langkah proses yang lebih oanjang daripada yang seharusnya sepanjang proses value stream.

\section{Saving Method}

Bowersox dalam Erina (2009) menyatakan bahwa Savings Matrix merupakan salah satu teknik yang digunakan untuk menjadwalkan sejumlah terbatas kendaraan dari suatui fasilitas dan jumlah kendaraan dalam armada ini dibatasi dan mereka mempunyai kapasitas maksimum yang berlainan. Tujuan metode ini adalah untuk memilih penugasan kendaraan dan routing sebaik mungkin. Sedangkan menurut Pujawan dan Mahendrawathi (2007), saving methode merupakan salah satu metode untuk meminimumkan jarak atau waktu atau ongkos dengan mempertimbangkan kendalakendala yang ada. Langkah-langkah yang harus dikerjakan dalam savng matrix adalah:

1. Mengidentifikasi matrik jarak

$>$ Menentukan jarak antara tempat awal ke masing-masing tujuan dan jarak antar tujuan

> Untuk sederhananya, menggunakan lintasan terpendek sebagai jarak antar lokasi yang nerupakan rumus phytagoras $J(1,2)=\sqrt{\left(x_{1}-x_{2}\right)^{2}+\left(y_{1}-y_{2}\right)^{2}}$,

dimana xi adalah koordinat $\mathrm{x}$ titik i dan yi adalah koordinasi y titik i

$>$ Apabila jarak riil antar lokasi diketahui, maka jarak riil tersebut lebih baik digunakan daripada dihitung secara teoritis

2. Mengidentifikasikan matrik penghematan (saving matrix), matrik penghematan menunjukkan besarnya penghematan jarak yang bisa diperoleh dengan menggabungkan dua tujuan menjadi satu rute

3. Mengalokasikan tujuan ke kendaraan atau rute. Alokasi dilakukan dengan menggabumgkan rute yang memiliki penghematan terbesar.

4. Mengurutkan tujuan dalam rute yang sudah terdefinisi 


\section{METODE}

\section{Pengumpulan Data}

Metode pengumpulan data yang digunakan dalam penelitian ini adalah dengan cara :

- Mengambil/mencatat data-data yang tersedia di perusahaan

- Wawancara atau brainstorming dengan PPL PT. $\mathrm{X}$ unit Kediri

Sementara data yang dibutuhkan dalam penelitian ini antara lain :

- Data plasma beserta populasi dan alamat yang sudah dikelompokkan sesuai klaster masingmasing PPL.

- Rata-rata jumlah jatah DOC yang diberikan oleh kantor pusat.

\section{Pengolahan Data}

Data yang sudah dikumpulkan selanjutnya diolah dengan metode saving matrix dengan langkah-langkah sebagai berikut :

1. Mengidentifikasi matrik jarak

Jarak yang digunakan untuk menyusun matrik jarak adalah jarak riil yang didapat dengan bantuan google maps dan dipilih jarak terpendek yang bisa dilewati. Jarak yang diambil adalah satuan kilometer.

2. Mengidentifikasikan matrik penghematan (saving matrix)

Asumsi awal : setiap plasma akan dikunjungi oleh seorang PPL secara eksklusif, sehingga akan ada rute sebanyak jumlah plasma yang harus dikunjungi

savings matrix mempresentasikan penghematan yang bisa direalisasikan dengan menggabungkan dua plasma ke dalam satu rute.

\section{Kantor}

Plasma 1

\section{Kantor}

\section{Plasma 1}

Gambar 1. Perubahan yang terjadi dengan menggabungkan plasma menjadi satu rute
Perubahan jarak yang terjadi adalah

$2 \mathrm{~J}(\mathrm{~K}, \mathrm{P} 1)+2 \mathrm{~J}(\mathrm{~K}, \mathrm{P} 2)-[\mathrm{J}(\mathrm{K}, \mathrm{P} 1)+\mathrm{J}$

$(\mathrm{P} 1, \mathrm{P} 2)+\mathrm{J}(\mathrm{P} 2, \mathrm{~K})]$

$=\mathrm{J}(\mathrm{K}, \mathrm{P} 1)+\mathrm{J}(\mathrm{K}, \mathrm{P} 2)-\mathrm{J}(\mathrm{P} 1, \mathrm{P} 2)$

Hasil tersebut diperoleh dengan asumsi bahwa jarak (Px,Py) sama dengan jarak (Py,Px)

Dapat digeneralisasi :

$\mathrm{S}(\mathrm{Px}, \mathrm{Py})=\mathrm{J}(\mathrm{K}, \mathrm{Px})+\mathrm{J}(\mathrm{K}, \mathrm{Py})-\mathrm{J}(\mathrm{Px}, \mathrm{Py})$

Dimana :

$\mathrm{J}(\mathrm{K}, \mathrm{Px})$ adalah jarak antara Kantor dengan Plasma $\mathrm{x}$

S (Px,Py) adalah penghematan jarak (savings) yang diperoleh dengan menggabungkan rute $\mathrm{Px}$ dan Py menjadi satu

Dengan rumus di atas matrik penghematan dapat dihitung untuk semua plasma

3. Mengalokasikan plasma ke dalam rute, diawali dengan menggabungkan plasma yang jika rute digabung akan menhasilkan penghematan yang paling besar. Penggabungan plasma ke dalam satu rute yang sama didasarkan pada jumlah plasma yang harus dikunjungi.

4. Mengurutkan plasma dalam rute yang sudah terdefinisi dengan metode nearest neighbour. Prinsip metode nearest neighbor adalah selalu menambahkan lokasi (plasma) yang jaraknya paling dekat dengan lokasi (plasma) yang kita kunjungi terakhir.

Rute yang sudah terbentuk pada tahap sebelumnya selanjutnya digunakan sebagai dasar untuk menentukan siklus jadwal pemasukan DOC oleh perusahaan kepada peternak mitra atau plasma. Jadwal Pemasukan DOC dilakukan secara mundur dari urutan rute yang sudah terbentuk untuk masing-masing PPL

\section{HASIL DAN PEMBAHASAN}

\section{Beberapa kondisi yang terjadi dalam Perusahaan}

1. PPL yang dimiliki oleh perusahaan berjumlah 3 orang dengan klaster plasma yang sudah terbentuk sebelumnya 
2. Jadwal kunjungan PPL ke plasma yang ditetapkan oleh manajemen PT. X adalah 2 kali dalam seminggu dimana hari kerja yang tersedia untuk melakukan kunjungan adalah senin, selasa, kamis, dan jum'at. Sementara hari rabu dan sabtu digunakan untuk melakukan rapat rutin di kantor dan mengunjungi plasma yang bermasalah, sehingga rute yang dimiliki oleh masing-masing PPL adalah 2 rute, rute pertama akan dikunjungi pada hari senin dan kamis, sedangkan rute kedua akan dikunjungi pada hari selasa dan jumat.

3. Perusahaan mengganti biaya transportasi yang dikeluarkan PPL sesuai dengan nota pembelian resmi SPBU yang ditunjukkan oleh PPL sehingga semakin tidak efisien jarak yang ditempuh oleh PPL maka biaya transportasi yang ditanggung perusahaan juga akan semakin besar.

\section{Hasil dengan Saving Matrix}

Perhitungan dengan metode saving matrix dilakukan untuk masing-masing klaster plasma yang ditangani oleh PPL. Lokasi plasma berada di wilayah Kediri dan sekitarnya. Peta Lokasi plasma dapat dilihat pada gambar 1 .

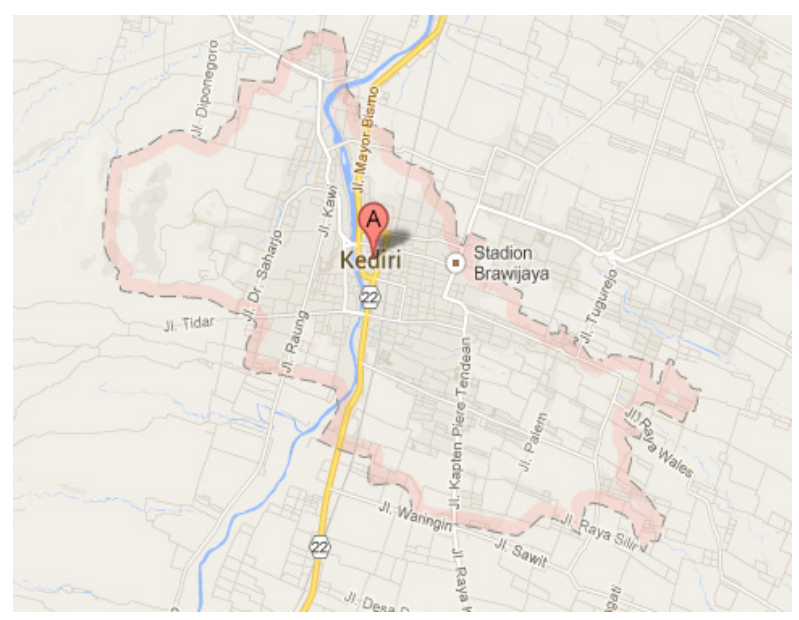

Gambar 2. Peta kota Kediri

\section{A. PPL I}

Plasma yang ditangani oleh PPL I berjumlah 31 plasma yang seanjutnya diberi kode A1 sampai dengan A31. Langkah awal adalah mengidentifikasi jarak antara lokasi Kantor (K) dimana para PPL memulai kegiatan kunjungannya dengan masingmasing plasma, serta jarak antar plasma. Matrik jarak selengkapnya dapat dilihat pada tabel 1. Dari matriks jarak tersebut selanjutnya disusun matriks penghematan dengan rumus yang sudah ditentukan yaitu :

$$
\mathrm{S}(\mathrm{Px}, \mathrm{Py})=\mathrm{J}(\mathrm{K}, \mathrm{Px})+\mathrm{J}(\mathrm{K}, \mathrm{Py})-\mathrm{J}(\mathrm{Px}, \mathrm{Py})
$$

Hasil perhitungan untuk penghematan selanjutnya menghasilkan matrik penghematan seperti yang ditunjukkan pada tabel 2. Langkah berikutnya adalah menyusun plasma-plasma tersebut menjadi dua rute yang kemudian dari rute yang terbentuk ditentukan urutannya dengan metode nearest neighbor, yaitu memilih plasma terdekat dari lokasi terakhir yang dikunjungi, diawali posisi PPL berada di Kantor. Rute pertama terdiri dari 16 plasma dan rute kedua terdiri dari 15 plasma dengan total jarak yang ditempuh masing-masing adalah 88 dan $151 \mathrm{KM}$. Dalam rute ke-2 jarak yang ditempuh lebih panjang karena ada suatu plasma yaitu A-7 yang berlokasi di kota Jombang yang terkadang dikunjungi pada hari lain, missal rabu atau sabtu. Rute tersebut diperoleh dengan mulai menggabungkan plasma yang memiliki penghematan paling besar. Hasil rute yang harus dikunjungi oleh PPL I selengkapnya dapat dilihat pada tabel 3 .

\section{B. PPL II}

Plasma yang ditangani oleh PPL II berjumlah 29 plasma yang seanjutnya diberi kode B1 sampai dengan B29. Langkah awal adalah mengidentifikasi jarak antara lokasi Kantor (K) dimana para PPL memulai kegiatan kunjungannya, serta jarak antar plasma. Matrik jarak selengkapnya dapat dilihat pada tabel 4. Dari matriks jarak tersebut selanjutnya disusun matriks penghematan dengan rumus yang sama untuk kasus PPL I. Hasil perhitungan untuk penghematan selanjutnya menghasilkan matrik penghematan seperti yang ditunjukkan pada tabel 5. Langkah berikutnya adalah menyusun plasmaplasma tersebut menjadi dua rute yang kemudian dari rute yang terbentuk ditentukan urutannya dengan metode nearest neighbor, yaitu memilih plasma terdekat dari lokasi terakhiryang dikunjungi, diawali posisi PPL berada di Kantor. Rute pertama terdiri dari 14 plasma dan rute kedua terdiri dari 15 plasma dengan total jarak yang ditempuh masingmasing adalah 153 dan 92 KM.. Rute tersebut diperoleh dengan mulai menggabungkan plasma yang memiliki penghematan paling besar. Hasil rute yang harus dikunjungi oleh PPL I selengkapnya dapat dilihat pada tabel 6 . 


\section{PPL III}

Plasma yang ditangani oleh PPL III hanya berjumlah 5 plasma dan sebuah own farm yang seanjutnya diberi kode $\mathrm{C} 1$ untuk own farm dan C2 sampai dengan C6 untuk kelima plasma yang ditangani. Own farm tetap diasumsikan sebagai plasma karena juga mendapat jadwal kunjungan. Hanya saja own farm mendapat jatah kunjungan secara eksklusif yaitu satu hari penuh sehingga pada kasus PPL III, langsung pada langkah ke-4 metode saving matrix yaitu menentukan urutan

Tabel 1. Matrik Jarak untuk Klaster Plasma PPL I kunjungan dengan metode nearest neighbor, yaitu memilih plasma terdekat dari lokasi terakhir yang dikunjungi, diawali posisi dari Kantor. Walaupun demikian langkah awal adalah tetap mengidentifikasi jarak antara lokasi Kantor (K) dimana para PPL memulai kegiatan kunjungannya, serta jarak antar plasma. Matrik jarak selengkapnya dapat dilihat pada tabel 7 , sedangkan hasil rute yang harus dikunjungi oleh PPL III selengkapnya dapat dilihat pada tabel 8 .

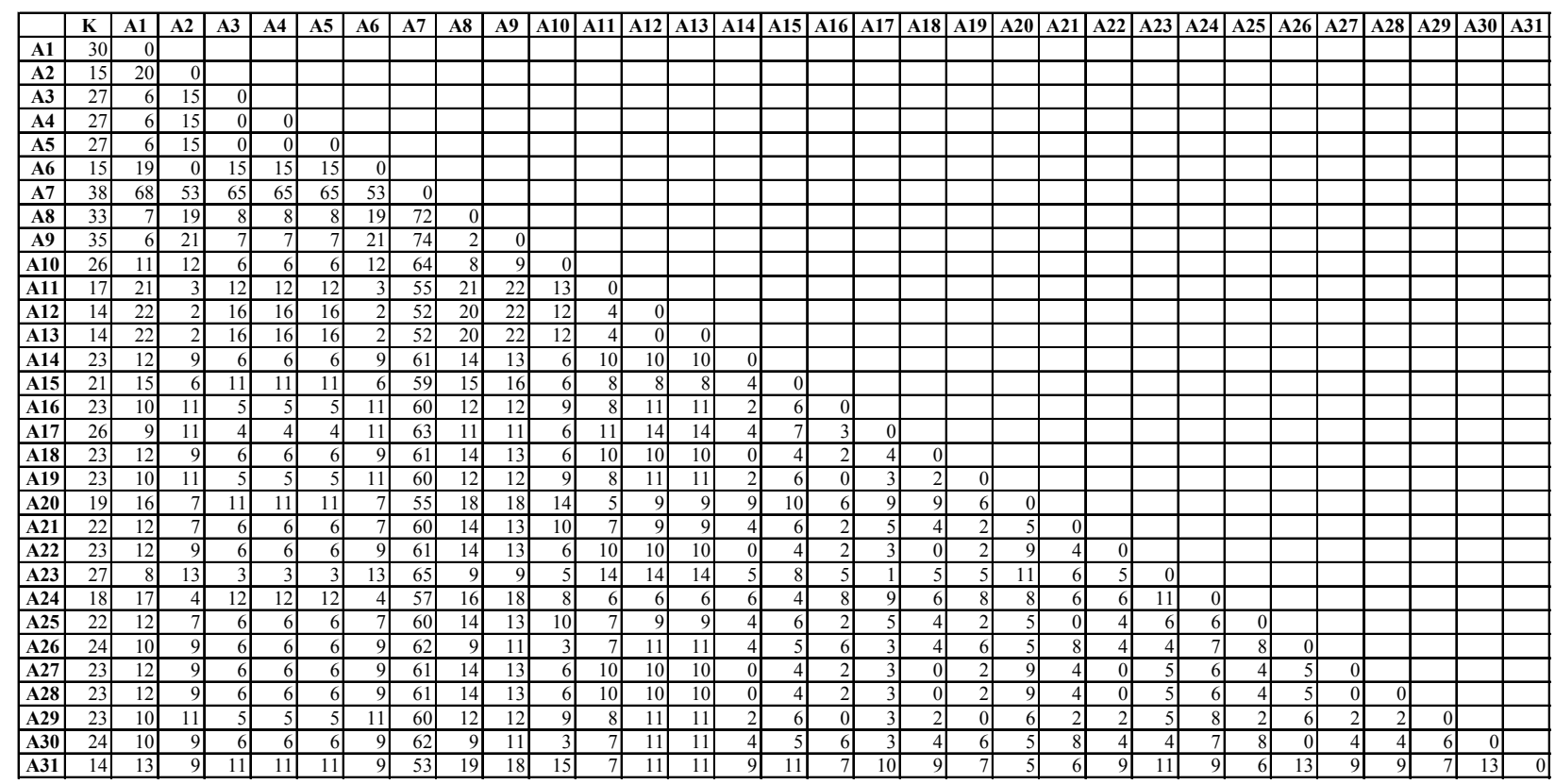

Tabel 2. Matrik Penghematan untuk Klaster Plasma PPL I

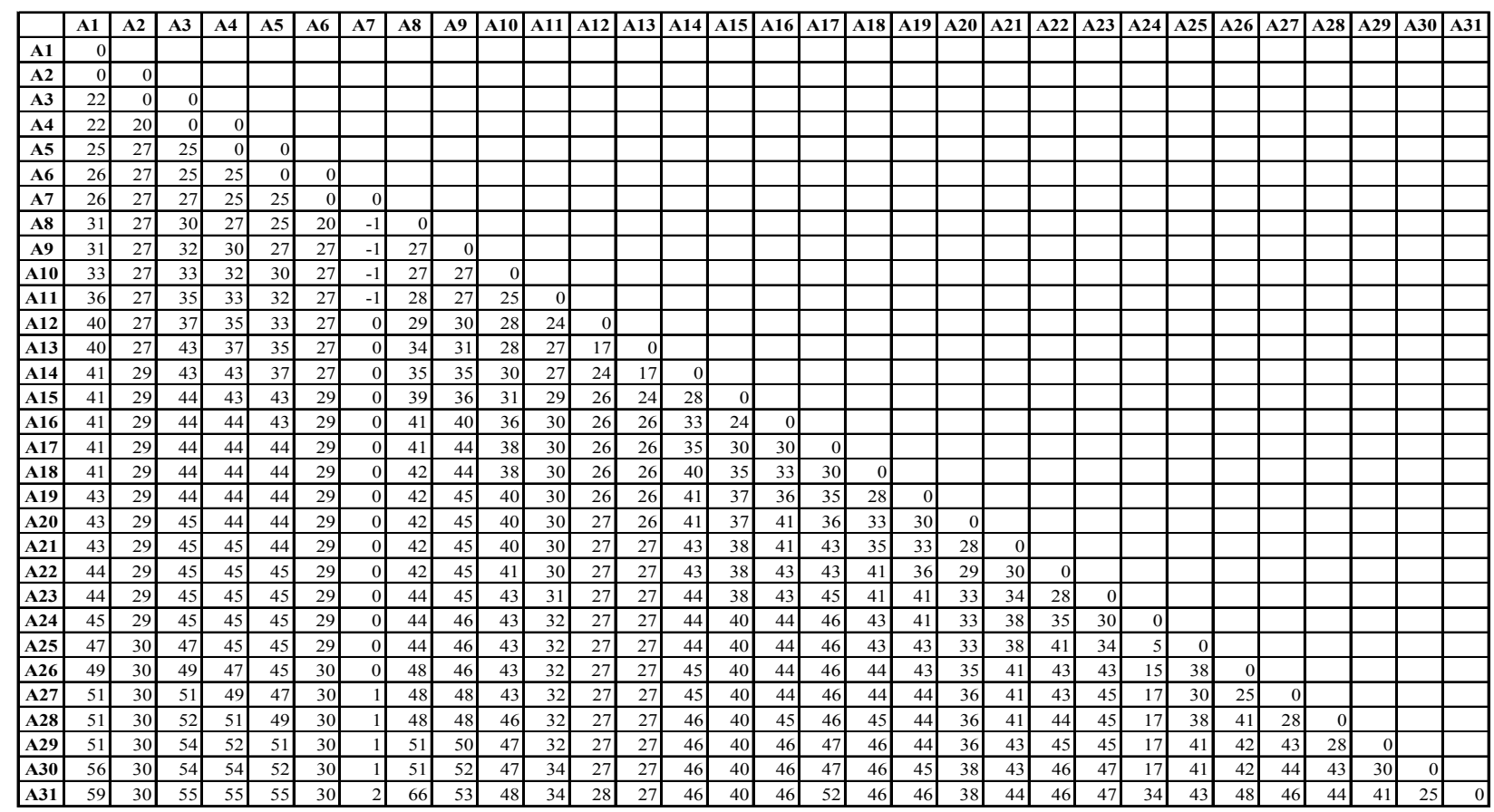


Tabel 3. Hasil Rute Kunjungan untuk PPL I

\begin{tabular}{|c|c|r||c|c|r|}
\hline \multicolumn{3}{|c|}{ Rute PPL I-1 } & \multicolumn{3}{c|}{ Rute PPL I-2 } \\
\hline No & Plasma & $\begin{array}{c}\text { Populasi } \\
\text { (ekor) }\end{array}$ & No & Plasma & $\begin{array}{c}\text { Populasi } \\
\text { (ekor) }\end{array}$ \\
\hline 1 & A-21 & 2,500 & 1 & A-12 & 7,000 \\
\hline 2 & A-25 & 2,500 & 2 & A-13 & 3,000 \\
\hline 3 & A-16 & 11,000 & 3 & A-2 & 2,000 \\
\hline 4 & A-19 & 3,000 & 4 & A-6 & 2,000 \\
\hline 5 & A-29 & 4,500 & 5 & A-11 & 3,000 \\
\hline 6 & A-3 & 16,000 & 6 & A-20 & 7,000 \\
\hline 7 & A-4 & 3,000 & 7 & A-31 & 4,500 \\
\hline 8 & A-5 & 1,500 & 8 & A-14 & 2,000 \\
\hline 9 & A-17 & 3,500 & 9 & A-18 & 2,000 \\
\hline 10 & A-23 & 5,000 & 10 & A-22 & 2,000 \\
\hline 11 & A-26 & 4,000 & 11 & A-27 & 6,000 \\
\hline 12 & A-30 & 1,500 & 12 & A-28 & 7,500 \\
\hline 13 & A-10 & 3,000 & 13 & A-15 & 6,000 \\
\hline 14 & A-8 & 2,500 & 14 & A-24 & 3,000 \\
\hline 15 & A-9 & 2,000 & 15 & A-7 & 6,500 \\
\hline 16 & A-1 & 2,000 & & & \\
\hline & & & & & \\
\hline
\end{tabular}

Tabel 4. Matrik Jarak untuk Klaster Plasma PPL II

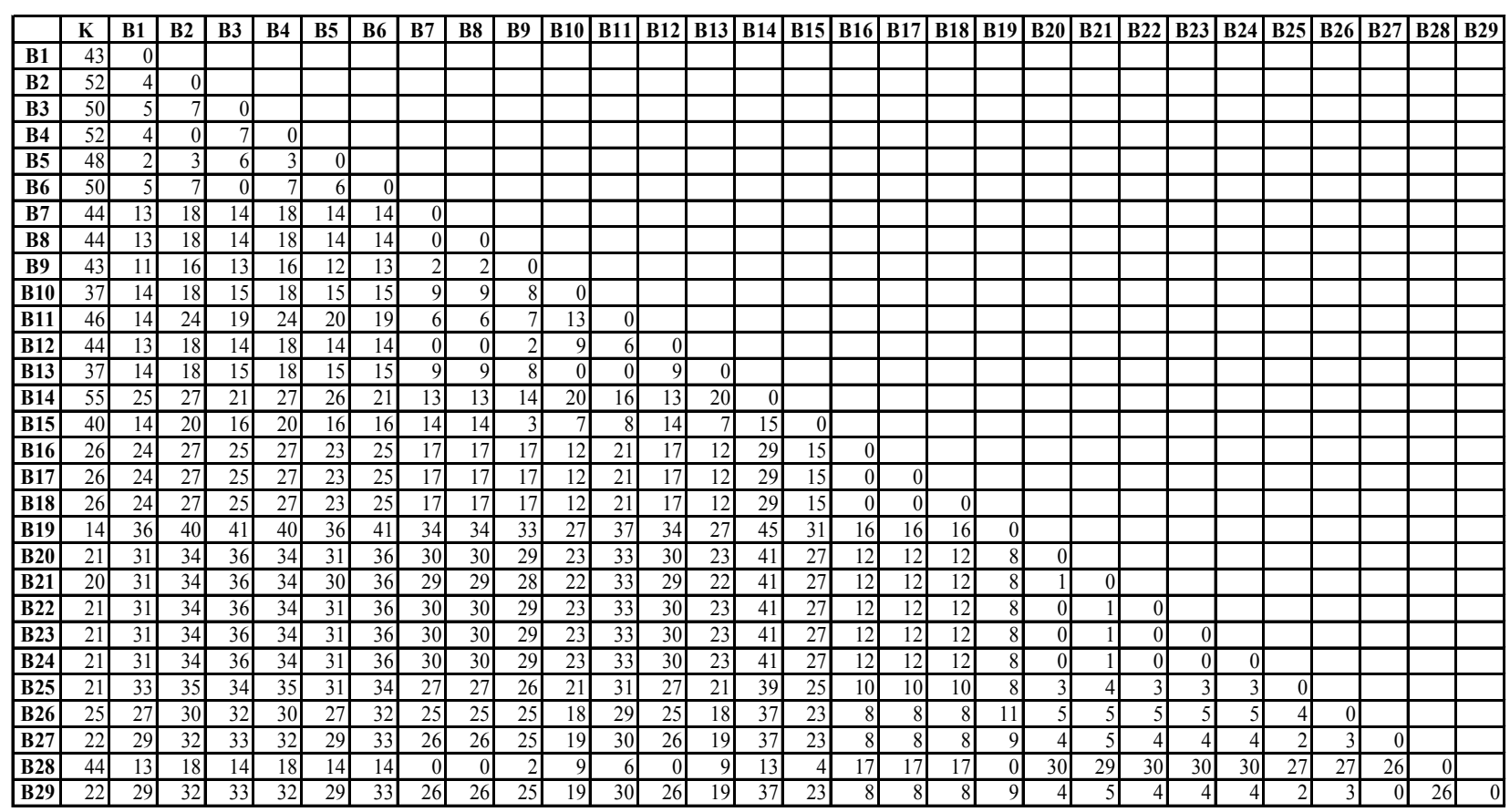


Tabel 5. Matrik Penghematan untuk Klaster Plasma PPL II

\begin{tabular}{|c|c|c|c|c|c|c|c|c|c|c|c|c|c|c|c|c|c|c|c|c|c|c|c|c|c|c|c|c|c|}
\hline & B1 & B2 & B3 & B4 & B5 & B6 & B7 & B8 & B9 & \begin{tabular}{l|l} 
B10 & \\
\end{tabular} & B11 & \begin{tabular}{|l|l|} 
B12 \\
\end{tabular} & \begin{tabular}{|l|l|l} 
B13 & B \\
\end{tabular} & B14 & \begin{tabular}{|l|l} 
B15 & P \\
\end{tabular} & B16 & \begin{tabular}{|l|l} 
B17 \\
\end{tabular} & \begin{tabular}{|l|l} 
B18 & . \\
\end{tabular} & B19 & \begin{tabular}{|l|l|l} 
B20 \\
\end{tabular} & \begin{tabular}{|l|l|} 
B21 \\
\end{tabular} & \begin{tabular}{|l|l} 
B22 \\
\end{tabular} & B23 & \begin{tabular}{|l|l|} 
B24 \\
\end{tabular} & B25 & B26 & \begin{tabular}{|l|} 
B227 \\
\end{tabular} & B28 & B29 \\
\hline B1 & \begin{tabular}{|l|}
0 \\
\end{tabular} & & & & & & & & & & & & & & & & & & & & & & & & & & & & \\
\hline B2 & 21 & 0 & & & & & & & & & & & & & & & & & & & & & & & & & & & \\
\hline B3 & 31 & 26 & 0 & & & & & & & & & & & & & & & & & & & & & & & & & & \\
\hline B4 & 32 & \begin{tabular}{|l|}
38 \\
\end{tabular} & 23 & 0 & & & & & & & & & & & & & & & & & & & & & & & & & \\
\hline B5 & 33 & 38 & 34 & 26 & 0 & & & & & & & & & & & & & & & & & & & & & & & & \\
\hline B6 & 33 & 39 & 35 & 38 & 26 & 0 & & & & & & & & & & & & & & & & & & & & & & & \\
\hline B7 & 33 & 39 & 35 & 38 & 38 & 23 & 0 & & & & & & & & & & & & & & & & & & & & & & \\
\hline B8 & 33 & \begin{tabular}{|l|}
39 \\
\end{tabular} & 35 & 39 & 38 & 34 & 24 & 0 & & & & & & & & & & & & & & & & & & & & & \\
\hline B9 & 36 & 39 & 35 & 39 & 38 & 35 & \begin{tabular}{|l|}
35 \\
\end{tabular} & 24 & 0 & & & & & & & & & & & & & & & & & & & & \\
\hline B10 & 36 & \begin{tabular}{l|l|}
42 \\
\end{tabular} & 37 & 39 & 38 & 35 & 35 & 35 & 24 & 0 & & & & & & & & & & & & & & & & & & & \\
\hline B11 & 41 & 42 & 39 & 39 & 38 & 35 & 35 & 35 & 35 & 24 & 0 & & & & & & & & & & & & & & & & & & \\
\hline B12 & 45 & \begin{tabular}{|l|}
47 \\
\end{tabular} & 39 & 42 & 38 & 35 & \begin{tabular}{|l|}
35 \\
\end{tabular} & \begin{tabular}{|l|}
35 \\
\end{tabular} & 35 & 35 & 23 & 0 & & & & & & & & & & & & & & & & & \\
\hline B13 & 45 & 51 & 43 & 42 & 41 & 37 & 35 & 35 & 35 & 35 & 33 & 24 & 0 & & & & & & & & & & & & & & & & \\
\hline B14 & 45 & 51 & 51 & 47 & 41 & 39 & 38 & 35 & 35 & 35 & 34 & 35 & 24 & 0 & & & & & & & & & & & & & & & \\
\hline B15 & 66 & 51 & 51 & 51 & 46 & 39 & 40 & 38 & 35 & 35 & 34 & 35 & 35 & 24 & 0 & & & & & & & & & & & & & & \\
\hline B16 & 66 & 71 & 51 & 51 & 51 & 43 & 40 & 40 & 38 & 35 & 34 & 35 & 35 & 34 & 23 & 0 & & & & & & & & & & & & & \\
\hline B17 & 69 & 71 & 72 & 51 & 51 & 51 & 44 & 40 & 40 & 37 & 34 & 35 & 35 & 35 & 33 & 24 & 0 & & & & & & & & & & & & \\
\hline B18 & 73 & 72 & 72 & 71 & 51 & 51 & 53 & 44 & 40 & 40 & 36 & 35 & 35 & 35 & 34 & 34 & 24 & 0 & & & & & & & & & & & \\
\hline B19 & 74 & 74 & 74 & 71 & 70 & 51 & 53 & 53 & 43 & 40 & 38 & 38 & 35 & 35 & 34 & 35 & 34 & 24 & 0 & & & & & & & & & & \\
\hline B20 & 74 & 78 & 77 & 72 & 70 & 72 & 53 & 53 & 52 & 44 & 38 & 40 & 37 & 35 & 34 & 35 & 35 & 34 & 26 & 0 & & & & & & & & & \\
\hline B21 & 74 & 78 & 80 & 74 & 72 & 72 & 70 & 53 & 52 & 51 & 42 & 40 & 40 & 37 & 34 & 35 & 35 & 35 & 27 & 35 & 0 & & & & & & & & \\
\hline B22 & 74 & 78 & 80 & 78 & 74 & 74 & 72 & 70 & 52 & 51 & 51 & 44 & 40 & 40 & 36 & 35 & 35 & 35 & 27 & 39 & 35 & 0 & & & & & & & \\
\hline B23 & 75 & 78 & 80 & 78 & 77 & 77 & 72 & 72 & 72 & 51 & 51 & 53 & 44 & 40 & 39 & 37 & 35 & 35 & 27 & 39 & 37 & 35 & 0 & & & & & & \\
\hline B24 & 75 & 79 & 80 & 78 & 78 & 80 & 84 & 72 & 72 & 70 & 51 & 53 & 51 & 43 & 39 & 40 & 37 & 35 & 27 & 39 & 37 & 39 & 35 & 0 & & & & & \\
\hline B25 & 88 & 80 & 80 & 78 & 78 & 80 & 85 & 84 & 80 & 70 & 78 & 53 & 51 & 52 & 42 & 40 & 40 & 37 & 27 & 40 & 37 & 39 & 39 & 14 & 0 & & & & \\
\hline B26 & 88 & 95 & 84 & 79 & 78 & 80 & 86 & 85 & 82 & 72 & 83 & 70 & 51 & 52 & 51 & 43 & 40 & 40 & 27 & 41 & 40 & 39 & 39 & 18 & 38 & 0 & & & \\
\hline B27 & 89 & 95 & 92 & 80 & 78 & 80 & 88 & 86 & 84 & 72 & 84 & 72 & 70 & 52 & 51 & 52 & 43 & 40 & 27 & 42 & 40 & 41 & 39 & 18 & 41 & 42 & 0 & & \\
\hline B28 & 91 & 97 & 95 & 95 & 79 & 80 & 88 & 88 & 85 & 72 & 84 & 86 & 72 & 80 & 51 & 52 & 52 & 43 & 28 & 42 & 40 & 42 & 41 & 20 & 41 & 44 & 40 & 0 & \\
\hline B29 & 911 & 104 & 100 & 97 & 92 & 84 & 88 & 88 & 85 & 74 & 85 & 88 & 72 & 86 & 80 & 53 & 53 & 53 & 58 & 42 & 40 & 42 & 42 & 39 & 42 & 44 & 44 & 40 & \\
\hline
\end{tabular}

Tabel 6. Hasil Rute Kunjungan untuk PPL II

\begin{tabular}{|c|c|r||c|c|r|}
\hline \multicolumn{3}{|c||}{ Rute PPL II-1 } & \multicolumn{3}{c|}{ Rute PPL II-2 } \\
\hline No & Plasma & $\begin{array}{c}\text { Populasi } \\
\text { (ekor) }\end{array}$ & No & Plasma & $\begin{array}{c}\text { Populasi } \\
\text { (ekor) }\end{array}$ \\
\hline 1 & B-1 & 3,500 & 1 & B-19 & 3,500 \\
\hline 2 & B-5 & 2,000 & 2 & B-20 & 2,000 \\
\hline 3 & B-2 & 11,000 & 3 & B-22 & 1,500 \\
\hline 4 & B-4 & 4,000 & 4 & B-23 & 2,500 \\
\hline 5 & B-6 & 2,000 & 5 & B-24 & 3,000 \\
\hline 6 & B-3 & 2,500 & 6 & B-21 & 3,000 \\
\hline 7 & B-9 & 2,500 & 7 & B-26 & 4,500 \\
\hline 8 & B-7 & 6,000 & 8 & B-27 & 8,000 \\
\hline 9 & B-8 & 6,000 & 9 & B-25 & 6,500 \\
\hline 10 & B-12 & 3,000 & 10 & B-29 & 2,000 \\
\hline 11 & B-28 & 6,000 & 11 & B-16 & 3,000 \\
\hline 12 & B-15 & 2,000 & 12 & B-17 & 1,000 \\
\hline 13 & B-11 & 6,000 & 13 & B-18 & 4,000 \\
\hline 14 & B14 & 4,500 & 14 & B-10 & 20,000 \\
\hline 15 & & & 15 & B-13 & 16,000 \\
\hline & & & & \\
\hline
\end{tabular}


Tabel 7. Matrik Jarak untuk Klaster Plasma PPL III

\begin{tabular}{|l|r|r|r|r|r|r|r|}
\hline & K & C1 & C2 & C3 & C4 & C5 & C6 \\
\hline C1 & 29 & 0 & & & & & \\
\hline C2 & 11 & 31 & 0 & & & & \\
\hline C3 & 16 & 36 & 7 & 0 & & & \\
\hline C4 & 16 & 36 & 7 & 0 & 0 & & \\
\hline C5 & 22 & 43 & 17 & 23 & 23 & 0 & \\
\hline C6 & 16 & 46 & 24 & 29 & 29 & 33 & 0 \\
\hline
\end{tabular}

Tabel 8. Hasil Rute Kunjungan untuk PPL III

\begin{tabular}{|c|c|c||c|c|r|}
\hline \multicolumn{3}{|c||}{ Rute PPL III-1 } & \multicolumn{3}{c|}{ Rute PPL III-2 } \\
\hline No & Plasma & $\begin{array}{c}\text { Populasi } \\
\text { (ekor) }\end{array}$ & No & Plasma & $\begin{array}{c}\text { Populasi } \\
\text { (ekor) }\end{array}$ \\
\hline 1 & C-1 & 30,000 & 1 & C-2 & 12,000 \\
\hline & & & 2 & C-3 & 7,000 \\
\hline & & & 3 & C-4 & 4,000 \\
\hline & & & 4 & C-5 & 3,500 \\
\hline & & & 5 & C-6 & 3,000 \\
\hline
\end{tabular}

\section{Penentuan Siklus Jadwal Pemasukan DOC}

Berbeda dengan kasus Vehicle Routing Problem (VRP) dimana rute disusun dengan kendala kapasitas kendaraan, maka rute yang terbentuk di atas hanya membagi plasma yang dimiliki masingmasing PPL menjadi 2 rute. Rute beserta urutan yang terbentuk selanjutnya digunakan sebagai dasar untuk jadwal pemasukan DOC. Pada PT. X jumlah DOC yang akan dimasukkan pada plasma merupakan jumlah yang ditentukan oleh Perusahaan pusat yang berkedudukan di kota Malang yang dengan rata-rata 50.000 ekor per minggu. Dari jumlah tersebut selanjutnya didstribusikan merata kepada 3 PPL yang dimiliki. Atas dasar rute yang sudah terbentuk dengan metode saving matrix maka perusahaan dapat menetukan plasma mana yang akan dimasuki DOC agar kunjungan PPL menjadi lebih terarah dengan jarak tempuh yang minimal.

Karena aturan dalam melakukan kunjungan adalah bahwa plasma dengan ayam yang lebih muda atau dengan kata lain ayam yang terakhir dimasukkan plasma adalah yang harus dikunjungi terlebih dahulu maka urutan pemasukan DOC harus dimulai dari urutan paling akhir dari daftar kunjungan PPL. Siklus setiap plasma antara pemasukan DOC dengan pemasukan DOC brikutnya dalah 7 (tujuh) minggu, yang terdiri dari periode penggemukan ayam rata-rata 5 minggu dan diikuti dengan pencucian dan sterilisasi kandang setelah proses pemanenan hingga kandang siap untuk dimasuki DOC kembali rata-rata meemrlukan waktu 2 minggu.

Dengan asumsi rata-rata DOC yang diberikan kantor pusat sebesar 50.000 ekor maka siklus jadwal pemasukan DOC secara lengkap dapat dilihat pada tabel 9. Siklus tersebut bisa berubah mengikuti kondisi di lapangan seperti jatah DOC yang diberikan oleh kantor pusat, pemanenan di bawah umur rata-rata, dan kondisi lain yang terjadi. Tetapi perusahaan tetap dapat menggunaka urutan pemasukan DOC pada sesuai urutan pada tiap rute PPL yang juga ditampilkan pada tabel 9 .

Tabel 9. Siklus Jadwal Pemasukan DOC pada Plasma

\begin{tabular}{|c|c|c|c|c|c|c|c|c|c|c|c|c|c|c|c|c|c|c|c|}
\hline \multirow[b]{2}{*}{ Minggu } & \multicolumn{3}{|c|}{ Pemasukan DOC PPL I-1 } & \multicolumn{3}{|c|}{ Pemasukan DOC PPL I-2 } & \multicolumn{3}{|c|}{ Pemasukan DOC PPL II-1 } & \multicolumn{3}{|c|}{ Pemasukan DOC PPL II-2 } & \multicolumn{3}{|c|}{ Pemasukan DOC PPL III-1 } & \multicolumn{3}{|c|}{ Pemasukan DOC PPL III-2 } & \multirow{2}{*}{$\begin{array}{c}\text { Total } \\
\text { Kapasitas } \\
\text { (ekor) }\end{array}$} \\
\hline & No & Plasma & $\begin{array}{c}\begin{array}{c}\text { Populasi } \\
\text { (ekor) }\end{array} \\
\end{array}$ & No & Plasma & $\begin{array}{c}\begin{array}{c}\text { Populasi } \\
\text { (ekor) }\end{array} \\
\end{array}$ & No & Plasma & \begin{tabular}{c|}
$\begin{array}{c}\text { Populasi } \\
\text { (ekor) }\end{array}$ \\
\end{tabular} & No & Plasma & \begin{tabular}{|c|}
$\begin{array}{c}\text { Populasi } \\
\text { (ekor) }\end{array}$ \\
\end{tabular} & No & Plasma & \begin{tabular}{c|}
$\begin{array}{c}\text { Populasi } \\
\text { (ekor) }\end{array}$ \\
\end{tabular} & No & Plasma & $\begin{array}{c}\begin{array}{c}\text { Populasi } \\
\text { (ekor) }\end{array} \\
\end{array}$ & \\
\hline \multirow{2}{*}{ I } & 1 & A-1 & 2,000 & 1 & A-7 & 6,500 & 1 & B14 & 4,500 & & & & 1 & C-1 & 30,000 & & & & \multirow{2}{*}{51,000} \\
\hline & 2 & A-9 & 2,000 & & & & 2 & B-11 & 6,000 & & & & & & & & & & \\
\hline \multirow{3}{*}{ II } & 3 & A- 8 & 2,500 & 2 & A-24 & 3,000 & 3 & B-15 & 2,000 & 1 & B-13 & 16,000 & & & & 1 & C-6 & 3,000 & \multirow{3}{*}{52,000} \\
\hline & 4 & A-10 & 3,000 & 3 & A-15 & 6,000 & & & & & & & & & & 2 & $\mathrm{C}-5$ & 3,500 & \\
\hline & 5 & $\mathrm{~A}-30$ & 1,500 & 4 & $\mathrm{~A}-28$ & 7,500 & & & & & & & & & & 3 & $\mathrm{C}-4$ & 4,000 & \\
\hline \multirow{2}{*}{ III } & 6 & A-26 & 4,000 & 5 & A-27 & 6,000 & 4 & B-28 & 6,000 & 2 & B-10 & 20,000 & & & & 4 & $\mathrm{C}-3$ & 7,000 & \multirow{2}{*}{50,000} \\
\hline & 7 & A-23 & 5,000 & 6 & A-22 & 2,000 & & & & & & & & & & & & & \\
\hline \multirow{3}{*}{ IV } & 8 & A-17 & 3,500 & 7 & A-18 & 2,000 & 5 & B-12 & 3,000 & 3 & B-18 & 4,000 & & & & 5 & $\mathrm{C}-2$ & 12,000 & \multirow{3}{*}{51,500} \\
\hline & 9 & A-5 & 1,500 & 8 & A-14 & 2,000 & 6 & B-8 & 6,000 & 4 & B-17 & 1,000 & & & & & & & \\
\hline & 10 & A-4 & 3,000 & 9 & A-31 & 4,500 & 7 & B-7 & 6,000 & 5 & B-16 & 3,000 & & & & & & & \\
\hline \multirow{3}{*}{ V } & 11 & A-3 & 16,000 & 10 & A-20 & 7,000 & 8 & B-9 & 2,500 & 6 & B-29 & 2,000 & & & & & & & \multirow{3}{*}{49,500} \\
\hline & & & & 11 & $\mathrm{~A}-11$ & 3,000 & 9 & B-3 & 2,500 & 7 & $\mathrm{~B}-25$ & 6,500 & & & & & & & \\
\hline & & & & & & & 10 & B-6 & 2,000 & 8 & $\mathrm{~B}-27$ & 8,000 & & & & & & & \\
\hline \multirow{3}{*}{ VI } & 12 & A-29 & 4,500 & 12 & A- 6 & 2,000 & 11 & B-4 & 4,000 & 9 & B-26 & 4,500 & & & & & & & \multirow{3}{*}{50,000} \\
\hline & 13 & A-19 & 3,000 & 13 & $\mathrm{~A}-2$ & 2,000 & 12 & B-2 & 11,000 & 10 & B-21 & 3,000 & & & & & & & \\
\hline & 14 & A-16 & 11,000 & 14 & $\mathrm{~A}-13$ & 3,000 & 13 & B-5 & 2,000 & & & & & & & & & & \\
\hline \multirow{5}{*}{ VII } & 15 & A-25 & 2,500 & 15 & $\mathrm{~A}-12$ & 7,000 & 14 & B-1 & 3,500 & 11 & B-24 & 3,000 & & & & & & & \multirow{5}{*}{28,000} \\
\hline & 16 & A-21 & 2,500 & & & & & & & 12 & B-23 & 2,500 & & & & & & & \\
\hline & & & & & & & & & & 13 & B-22 & 1,500 & & & & & & & \\
\hline & & & & & & & & & & 14 & B-20 & 2,000 & & & & & & & \\
\hline & & & & & & & & & & 15 & B-19 & 3,500 & & & & & & & \\
\hline
\end{tabular}




\section{KESIMPULAN}

Dari penelitian yang dilakukan, dapat ditarik beberapa kesimpulan yaitu :

1. Rute yang terbentuk untuk masing-masing PPL terdiri dari dua rute yang didasarkan pada hari kerja yang tersedia, dimana urutan yang terbentuk adalah :

a. Rute pertama PPL I : Kantor, A-21, A-25, A-16, A-19, A-29, A-3, A-4, A-5, A-17, A-23, A-26, A-30, A-10, A-8, A-9, A-1, Kantor

b. Rute kedua PPL I : Kantor, A-12, A-13, A-2, A-6, A-11, A-20, A-31, A-14, A-18, A-22, A-27, A-28, A-15, A-24, A-7, Kantor

c. Rute pertama PPL II : Kantor, B-1, B-5, B-2, B-4, B-6, B-3, B-9, B-7, B-8, B-12, B-28, B-15, B-11, B-14, Kantor

d. Rute kedua PPL II : Kantor, B-19, B-20, B-22, B-23, B-24, B-21, B-26, B-27, B-25, B-29, B-16, B-17, B-18, B-10, B-13, Kantor

e. Rute pertama PPL III : Kantor, C-1 (Own farm), Kantor

f. Rute kedua PPL III : Kantor, C-2, C-3, C-4, C-5, C-6, Kantor

Urutan tersebut dapat diloncati jika pada plasma yang bersangkutan sedang tidak ada populasi ayam atau berada pada masa pembersihan setelah masa panen dan persiapan untuk pemasukan DOC berikutnya.

2. Siklus jadwal pemasukan DOC didapat dengan membalik urutan rute yang harus dikunjungi PPL dan dapat digunakan sebagai dasar bagi perusahaan maupun PPL untuk menentukan plasma mana yang harus dimasuki DOC, dimana urutan pemasukan untuk masing-masing rute adalah sebagai berikut :

a. Urutan pemasukan DOC berdasar rute pertama PPL I : A-1, A-9, A-8, A-10, A-30, A-26, A-23, A-17, A-5, A-4, A-3, A-29, A-19, A-16, A-25, A-21

b. Urutan pemasukan DOC berdasar rute kedua PPL I : A-7, A-24, A-15, A-28, A-27, A-22, A-18, A-14, A-31, A-20, A-11, A-6, A-2, A-13, A-12.

c. Urutan pemasukan DOC berdasar rute pertama PPL II : B-14, B-11, B-15, B-28,
B-12, B-8, B-7, B-9, B-3, B-6, B-4, B-2, B-5, B-1.

d. Urutan pemasukan DOC berdasar rute kedua PPL II : B-13, B-10, B-18, B-17, B-16, B-29, B-25, B-27, B-26, B-21, B-24, B-23, B-22, B-20, B-19

e. Urutan pemasukan DOC berdasar rute pertama PPL III hanya C-1 (own farm)

f. Urutan pemasukan DOC berdasar rute kedua PPL III : C-6, C-5, C-4, C-3, C-2.

Jumlah plasma yang dmasuki DOC setiap minggunya bervariasi tergatung pada jatah DOC yang diberikan oleh kantor pusat dan kapasitas populasi yang dimiliki oleh plasma.

\section{DAFTAR PUSTAKA}

Erlina P. (2009). Mengoptimalkan Biaya Transportasi untuk Penentuan Jalur Distribusi Produk " $X$ " dengan Metode Saving Matriks. Jurnal Penelitian Ilmu Teknik Vol.9, No.2 Desember 2009 : 143-150

Gasperz, Vincent (2007). Lean Six Sigma for Manufacturing and Service Industries, Gramedia Pustaka Utama, Jakarta

Pujawan, I Nyoman dan ER, Mahendrawathi (2007). Supply Chain Management, Gunawidya, Surabaya

Sholikin, Huda WS. (2011). Manajemen Pemeliharaan Ayam Broiler di Peternakan UD. Hadi PS Kecamatan Nguter Kabupaten Sukoharjo, Tugas Akhir, Program Diploma III Agribisnis Peternakan, Universitas Sebelas Maret, Surakarta

Sofyan,Ahmad.(2006). Strategi Kemitraan dalam Saluran Distribusi untuk Meningkatkan Kinerja Bisnis (Studi Empiris Kemitraan Ternak Broiler di Semarang, Kudus dan Salatiga), Tesis, Program Studi Magister Manajajemen Program Pascasarjana Universitas Diponegoro, Semarang. 